\title{
An Investigation of Doctoral Dissertation Abstracts Written Between 2010-2017 in Turkey
}

\section{Türkiye'de 2010-2017 Yıllarında Tamamlanmış Olan Doktora Tez Özetlerinin İncelenmesi}

\author{
Nuri Can AKSOY* (iD) Ersoy KARABAY** (D) Esra EKER-DURMUŞ ${ }^{* * *}$ (D) \\ Mehmet GÖKTAŞ**** (D) Fatma ÇİLOĞLAN-KONUR***** (D)
}

Received: 30 December 2020

Research Article

Accepted: 17 March 2021

\begin{abstract}
This case study, based on qualitative research, aims to examine the doctoral dissertation abstracts written between 2010-2017. Therefore, in education, 3463 doctoral dissertations abstracts were accessed through Turkey's National Thesis Center website. The researchers developed an abstract review form. Each dissertation abstract was examined independently by two experts. Abstracts were examined by using the document analysis method. While almost all abstracts included aims and findings, most of them did not mention sample and data collection tools. However, a number of abstracts included data collection and sampling methods, and few abbreviations and references were used. The number of doctoral dissertations did not differ significantly regarding gender over the years. In conclusion, it is observed that there is insufficient information regarding dissertation abstracts, especially in method. The differences in dissertation abstracts, not only between university programs but also within universities, make it difficult to obtain an idea of the dissertations. In institutes' dissertation writing guides, the abstracts should be expressed in a new standard national template by considering the required qualifications.
\end{abstract}

Keywords: Abstract, academic writing, doctoral dissertation, education, postgraduate.

ÖZ: Nitel araştırma desenlerinden durum çalışması modelinde olan bu çalışmada 2010-2017 yılları arasında yazılan doktora tez özetlerinin incelenmesini amaçlanmıştır. Bu amaç doğrultusunda, Türkiye ulusal tez merkezi adresinden eğitim alanındaki 3463 doktora tez özetine ulaşılmıştır. Araştırmacılar tez özeti inceleme formu geliştirmiştir. Özetler doküman analizi yöntemi kullanılarak analiz edilmiştir. Her bir özet iki farklı uzman birbirlerinden bağımsız olarak incelenmiştir. Tez özetlerinin neredeyse tamamına yakınında amaç, bulgulara yer verildiği, çoğunda örneklemden ve veri toplama araçlarından bahsedilmediği görülmüştür. Bununla birlikte az sayıda tezde veri toplama ve örnekleme yöntemine yer verildiği, az sayıda kısaltma ve referans kullanıldığg görülmüştür. Yıllar içinde doktora tez sayılarının cinsiyete göre anlamlı farklılık göstermediği bulunmuştur. Sonuç olarak tez özetlerinde özellikle yöntem bilgisi eksikliği olduğu görülmektedir. Üniversiteler arasında, hatta üniversitelerin kendi içerisindeki programlardaki doktora tez özeti farklılıkları tez hakkında fikir edinilmesini zorlaştırmaktadır. Enstitülerin tez yazım kılavuzlarında, tez özetlerinin, gerekli nitelikler dikkate alınarak ulusal yeni bir şablonda ifade edilmelidir.

Anahtar kelimeler: Özet, akademik yazı, doktora tezi, eğitim, lisansüstü.

* Corresponding Author: Asst. Prof. Dr., Hasan Kalyoncu University, Gaziantep, Turkey, ncan.aksoy@hku.edu.tr, https://orcid.org/0000-0001-6087-8884

** Asst. Prof. Dr., Ersoy Karabay, Kırşehir Ahi Evran University, Kırşehir, Turkey, ekarabay@gmail.com, https://orcid.org/0000-0002-9499-2009

*** Res. Asst., Hasan Kalyoncu University, Gaziantep, Turkey, esra.eker@hku.edu.tr, https://orcid.org/0000-00019178-4696

**** Res. Asst., Hasan Kalyoncu University, Gaziantep, Turkey, goktaspdr@gmail.com, https://orcid.org/00000003-3771-3488

***** Res. Asst., Hasan Kalyoncu University, Gaziantep, Turkey, fatma.ciloglan@hku.edu.tr, https://orcid.org/00000003-4456-3772

\section{Citation Information}

Aksoy, N. C., Karabay, E., Eker-Durmuş, E., Göktaş, M., \& Çiloğlan-Konur, F. (2021). An investigation of doctoral dissertation abstracts written between 2010-2017 in Turkey. Kuramsal Eğitimbilim Dergisi [Journal of Theoretical Educational Science], 14(2), 246-263. 
Researchers need an abstract in an academic text as it summarizes the main focus. Most readers find the title and abstract sufficient to the article and often scan through other sections (Hall, 2013). Indeed, since they represent the elaboration of the title and the outline of the entire article, abstracts (if well-structured) provide readers detailed information about the content of the article. Abstract as a preliminary reading stage: 1) introduces the study and appeals to the reader, ultimately helping readers to decide whether to read the full text (or some of the text); 2) provides some language preparations for the text, where necessary, by mentioning the keywords and key concepts used in the article; 3) provides the outline of the article, and 4) helps to understand the purpose and text format of the authors. As a post-reading phase, abstracts help reinforce or reflect on what is being read, and readers relate the text to their knowledge and views. In this sense, research abstracts have a critical role in obtaining preliminary information about studies (Salager-Meyer, 1990).

Due to their practical functions and concise content, abstracts have been the tools used to obtain effective and fast information since the 1960s (Chan \& Foo, 2001). The American National Institute of Standards (ANIS) describes an abstract as follows: "It is an abbreviated, complete representation of the content of a document, preferably prepared to be published by the author (s)" (ANIS, 1979, p. 1, as cited in Bhatia \& Genre, 1993). An abstract, which is one of the parts of research, is the first part where the reader gets information about the research (Büyüköztürk, Kılıç-Çakmak, Akgün, Karadeniz, \& Demirel, 2017). It should not be repetitive and should capture the general idea with the most essential and representative sentences taken from the text, and it should be as short as possible. Hovy and Lin (1999) define abstract as content produced from one or more texts, containing a significant portion of the information in the original text, and no longer than half of the original text. An abstract is an intensified representation of the research content and informative short text about the research with the most important information. Often researchers can reach only the abstract of the research. Students enrolled in the doctoral program are the researchers who have the potential to become qualified faculty members in the future of the countries and are expected to carry out the research and development activities required for the progress of the country.

Ph.D. graduates usually hold academic positions, senior positions in the bureaucracy, and specialist or executive positions in the private sector. One indication of the quality of doctoral education is the quality of a doctoral dissertation. One of the first read parts of the doctoral dissertation is the abstracts. The quality of the dissertation abstract might be evaluated as an indicator of the quality of doctoral education and the quality of the dissertation content. One of the important issues that have been considered in education research in Turkey is whether doctoral dissertation abstracts are consistent with the rules. Abstracts play an important information-sharing role (Fidel, 1986; Pinto \& Lancaster, 1999; Tenopir, 1985). Thus, many researchers (Berkenkotter \& Huckin, 1995; Dronberger \& Kowitz, 1975) examined the role of abstracts in the process of obtaining academic knowledge acquisition. In their study, Berkenkotter and Huckin (1995) stated that scientists follow a scanning strategy to access new information and that the strategy includes title and abstract reading steps. Therefore, titles and abstracts have an important role in deciding whether to read the research. Similarly, when Dronberger and Kowitz (1975) investigated the study abstracts 
published in the Education Research, they concluded that the reading rate of the abstracts is much higher compared to the reading rate of the entire study.

With the rapid increase in the world population, the education level in the world population has also been increasing in the last twenty years. There is a significant increase when considering the gross enrollment rates and higher education enrollment rates that show the ratio of the total number of the students enrolled in a certain level of education to the theoretical age group of that level of education in a given academic year. The speed and amount of this increase have been linked to the economic levels of the countries. In this sense, 1.500 of the 4.500 universities in the United States of America (USA), one of the world's leading economies, offer doctorate programs (Ph.D. Study in the USA, 2020). The number of graduates from the USA's doctorate programs increased by fifty percent during 2000-2018, and 4.5 million graduates completed these programs (U.S. Census Bureau, 2019). There was a rapid increase in the number of universities and institutes in the last decade in Turkey. With this quantitative increase, as of 2018, there were 5,735 doctorate programs in 155 universities that offered doctorate degrees. In addition, 94,840 students were doing their doctorate degrees in these programs (Council of Higher Education [CHE], 2018). This increase in Turkey has increased the number of doctoral programs and graduates from these programs. While the number of Ph.D. graduates was 4500 annually as of the end of 2013, it reached 6100 yearly as of the end of 2017. Scientific, technological, and academic competence led to the acquisition of a doctorate as a reward. Therefore, doctorate education is perceived as the highest level of advanced education worldwide and seen as the main priority of 21st-century universities (CHE, 2016).

Swales (1985) designed a research article format within a three-part structure identified and sequenced as Introduction (I), Method (M), Results (C), and Discussion (D), that is, IMRD. Other researchers have adapted the abstract of the research, adhering to this IMCD structure (Chan \& Foo, 2000; Dos Santos, 1996; Keogh, 1994; SalagerMeyer, 1990). In the analysis, Hyland's (2000) classification technique consists of Introduction $(\mathrm{I})$, purpose $(\mathrm{P})$, findings $(\mathrm{F})$, and the result $(\mathrm{R})$ is frequently used. A thesis summary should include main titles such as purpose, method, findings, and suggestions.

In a comparison between abstracts written in universities that have and do not have dissertation writing guidelines in Turkey, significant differences were found in terms of method and the statement of the problem in the study. In addition, it was observed that the ranking of the textual elements of the abstracts written in universities with a guideline (Introduction + Method + Findings + Results) is more consistent than universities without one (Ülker, 2012). In dissertation abstracts, it is stated that the purpose of the dissertation, the measurement tools, method, content, and significant findings should be present, but the sources should not be cited in the abstracts (Büyüköztürk et al., 2017; KTÜ, 2004). In addition, it is stated that the elements such as diagrams and formulas, and abbreviations should not be used in the abstract. Long terms should not be abbreviated unless they are used several times in the abstract and should be abbreviated in the text appropriately (Aktaş \& Uzuner-Yurt, 2015). When the factors determining the quality of the abstract are analyzed, it is seen that unnecessary details and detailed information should not be included in the abstract (Day, 2000). Higher education institutions cannot be evaluated independently of their social structure. On the contrary, the structural features, its introduction, and the conditions of higher education 
affect the form of the social structure. In this context, higher education institutions also play an important role in transforming gender roles (Savaş, 2018; TÜİK, 2017)

Differences can be seen when education in Turkey is analyzed in terms of gender distribution and accessibility between female and male students during the transition to secondary education. These gender differences, which are seen during the transition to secondary education, started to change from the beginning of the 2000s. According to the Turkish Statistical Institute's (TSI) 2016 data, an increase is observed in the female students' schooling rate. While the gender equality index, which expresses the level of schooling (balance) of female and male students, is getting closer to 1, it expresses the equality between genders; values greater than 1 represent a change in favor of female students, values less than one is in favor of male students. This rate presented a result that generally shows equality as 1.009 for primary education, .943 for secondary education, and .964 for higher education in 2016 (TSI, 2017). Thus, it can be stated that female students in Turkey have achieved an equal opportunity with male students in recent years.

An increase in the number of the current universities is an expected situation depending on the demands in education. This increase affected the involvement of women in higher education institutes as students and academicians. Women's involvement in higher education institutions in Turkey can be examined in three phases historically. In the first phase, women who found employment in academia with the principles provided by Atatürk began to become numerically more visible in academic life with the adoption process of these principles in the second period between 1940 and 1980. Lastly, with the opening of foundation universities in the 1990s, women were involved even more in academic life (Özbilgin \& Healy, 2004). With this increase, the rate, which was \%19 in the 1960s, increased to \%34.6 in 1999 and \%44 at present (CHE, 2019). In terms of career steps, which usually begin with a research assistant position and go up to the professorship at the highest level, the percentage of male and female research assistants who have taken office is equally stated as $50 \%$. However, in the percentage of the gender distribution of professors, women were seen to decline down to \%30 (CHE, 2019).

When the distribution of academics by gender is examined in Western countries, the percentage of female professors in European Union countries is $20 \%$, according to the European Union (2013). In Turkey, the percentage of female academics is higher than in European Union countries, and this rate is given as $28 \%$. This situation is not much different in the United Nations. A study conducted in the United Nations showed that women's recruitment to permanent positions is less likely than men's. In 2015, women were nominated for about half $(48.9 \%)$ of all permanent positions, while only $38.4 \%$ of women were able to be recruited. Women had a ratio of more than half of assistant professor positions $(51.5 \%)$ and close to the threshold in associate professor positions (44.9\%), according to 2015 data. In the professor position, women had less than a third $(32.4 \%)$. Women in academia performed more than half of all instructor positions $(57.0 \%)$ in the lowest-ranking positions. While $22.1 \%$ of women worked untenured in faculties, this rate was $16.8 \%$ for men (Catalyst, 2019). The fact that women, who make up half the population, also take part in academic tasks will pave the way for increasing and diversifying the number of researches. 
While the institutes' dissertation guidelines examined by the researchers contained formal requirements for the abstract, no information about the requirements for the contents of the abstract was found. There have been some effective studies on the sections of research articles so far (Chan \& Foo, 2000; Dos Santos, 1996; Keogh, 1994; Salager-Meyer, 1990), introduction (e.g., Swales, 1981, 1990, 2004) on discussion (e.g., Holmes, 1997; Hopkins \& Dudley-Evans, 1988) and on the results (e.g., Brett, 1994; Williams, 1999). However, although the dissertation abstracts have a key role in deciding whether to read the whole dissertation, there is scant research on this subject in the literature (Tavşancıl et al., 2010; Ülker, 2012). This research examines the abstract sections of all the doctoral dissertations written between 2010 and 2017 in Turkey in education using a form developed for its purpose. In this sense, it is thought that this study will inform researchers and decision-makers about how well the abstract section, perhaps the first place to be read in research, is written and will guide the researchers who are going to write a dissertation.

\section{Research Questions}

1. Are the doctoral dissertation abstracts written in education between 2010-2017 in Turkey produced in accordance with the abstract writing rules of the institutions?

2. Is there a statistical difference between gender over the years?

\section{Significance of the Study}

Although there are a few studies that examine the research abstracts (Karagöl, 2020; Şen, 2019; Tavşancıl et al., 2010; Ülker, 2012), there is no study that investigates the content of the doctoral dissertation abstracts in terms of form, especially in the field of education. Also, there were no similar studies examining all doctoral dissertation abstracts in a certain period of time. This research is the first one that explores the discourse structures of doctoral dissertation abstracts in Turkey. Some studies examine doctoral dissertations; however, no other research has been found that looks abstracts in terms of thesis abstract writing criteria. In addition, the abstract format in the dissertation guidelines of the institutes is examined for the first time with this research. Aiming to fill a gap in the field, the present study intends to attribute inexperienced researchers globally recognized academic discourse expression by developing awareness of the content and thematic structure organizations of academic discourse. For researchers, it is vital to have a standard dissertation abstract format among institutes or in each institute to ensure that dissertation has standards in scientific and common language. The results of the study are expected to be helpful to researchers and institute administrators. In addition, this study is also significant in terms of providing researchers, experts, and managers an idea of the applications in Turkey.

\section{Method}

\section{Research Design}

The research was designed as a case study based on the qualitative research model, one of the qualitative research designs. Yin (1994) defines a case study as researching an event in the context of real life. In this study, document analysis was used under the case study model. In the case of studies, besides observations and 
interviews, records/ documents can also be examined. Documents can be personal, popular culture, and official documents (Bogdan \& Biklen, 1998). In this research, doctoral dissertation abstracts, which are official documents, were examined.

\section{Population and Sampling}

Within the scope of the research, 3489 doctoral dissertations written in education between 2010-2017 were accessed, and 3463 of them were included in the research. In the research, no sampling method was made, and an attempt was made to access all the dissertations related to education through the website of CHE "https://tez.yok.gov.tr/UlusalTezMerkezi/". The names of dissertations were not included in the research, and they were given eight-digit codes. While the first four digits of the eight-digit codes indicate the year the dissertation was completed, the last four digits ended with a four-digit number, regarding the time order that started with a thousand in the year when the dissertation was completed. For example, a dissertation completed in 2015 and 300th in the dissertation ranking in 2015 was coded as 20151300. In this case, the dissertation codes start with 20101001 and end with 20171149.

\section{Data Collection}

This study aimed to investigate the doctoral dissertation abstracts completed during 2010-2017 in Turkey. For this purpose, the dissertations, written during 20102017 in education and published on the National Thesis Center of Turkey website, were examined. The search was done on the dissertation search page of the $\mathrm{CHE}$ (https://tez.yok.gov.tr/UlusalTezMerkezi/) using the advanced search option. The words to be searched are "education", the area to be searched is "all", the group is "social", and the leave status is "on leave". Words to be searched were determined as "Education, Year; 2010-2017, Thesis type; doctoral." and the search was carried out accordingly. After this screening, a total of 3489 doctoral dissertations were reached. However, the abstract of the 26 theses were not included in the study because they could not be found anywhere in the text in the pdf document. Later, these dissertations were excluded from the research. A total of 3463 dissertations, 465, 500, 525, 526, 562, 430, 306, and 149 dissertations were reached respectively from 2010 to 2017.

\section{Instrument}

Throughout the research, the "Dissertation Abstract Evaluation Form" (Appendix-1) including 18 different aspects (dissertation year, dissertation code, purpose, academic tone, research design, sampling method, sample group, data collection, data collection tools, data analysis, findings, suggestion, information that should not be abbreviated, reference, university name, department name, researcher gender, and title of the advisor) was developed by the researchers to provide a standard in the analysis of the dissertation abstracts. The researchers, five education experts, constantly updated the evaluation form during the pilot study. The main purpose of the pilot study was to determine whether the form works or not. When evaluating the dimensions, the absence of the relevant section in the form was coded with " 0 " and the existence of the relevant section was coded with "1".If it is inappropriate, the code "2" is used. Relevant numerical symbols are used in expressing the year and dissertation code. While the symbols were used to state the name of the university and the 
department, gender is being stated as " 1 " for women, " 2 " for men, and consultants were coded as "1" for Dr. "2" for Assoc. Dr. and "3" for Prof. Dr.

\section{Data Analysis}

The descriptive analysis approach was used to analyze the data in this study, which focused on investigating the doctoral dissertation abstracts written in Turkey in education during 2010-2017 focusing on the abstract writing rules. The data were analyzed through the examination of documents (doctoral dissertations). Since the examination of the dissertation abstracts is the primary purpose of the research, document analysis was preferred. The main purpose of document analysis is to analyze written materials that contain information about the phenomenon or facts that are targeted to be investigated (Yıldırım \& Şimşek, 2008).

Two researchers coded each dissertation abstract, and then the items that could not be reconciled were reevaluated by a third researcher. The "Doctoral Dissertation Abstract Evaluation Form" developed by the researchers was used in the evaluation process. As a result of the document analysis, the data was digitized. In other words, qualitative data has been quantified. The data obtained were expressed in frequency and percentage, chi-square test and direct quotations were included. The chi-square test was carried out to determine whether there was a difference between years in abstract numbers according to gender. Microsoft Excel and IBM SPSS 22 programs were used to analyze the data.

\section{Results}

The first concern of the study was to examine whether the doctoral dissertation abstracts written in education between 2010-2017 in Turkey were produced in accordance with the abstract writing rules of the institutions. The following findings were achieved as a result of the analysis.

The information regarding the purpose, academic tone, research design, sampling, sampling method, data collection, data collection tools, data analysis, findings, suggestions, information that should not be stated, abbreviations, and reference in the doctoral dissertations written between 2010 and 2017 are shown in Table 1.

\section{Table 1}

The Status of Stating the Sections of the Research in the Dissertation Abstracts

\begin{tabular}{|c|c|c|c|c|c|c|}
\hline \multirow{2}{*}{ Parts of the abstra } & \multicolumn{2}{|c|}{ Absent } & \multicolumn{2}{|l|}{ Present } & \multicolumn{2}{|c|}{ False } \\
\hline & $\mathrm{f}$ & $\%$ & f & $\%$ & $\mathrm{f}$ & $\%$ \\
\hline Purpose & 314 & 9.1 & 3135 & 90.5 & 14 & .4 \\
\hline Academic tone & 233 & 6.7 & 3230 & 93.3 & - & - \\
\hline Research design & 1520 & 43.9 & 1943 & 56.1 & - & - \\
\hline Sampling & 828 & 23.9 & 2631 & 76 & 4 & .1 \\
\hline
\end{tabular}




\begin{tabular}{|c|c|c|c|c|c|c|}
\hline Sampling method & 2938 & 84.8 & 524 & 15.1 & 1 & .0 \\
\hline Data collection & 1511 & 43.6 & 1951 & 56.3 & 1 & .0 \\
\hline Data collection tools & 1233 & 35.6 & 2229 & 64.4 & 1 & .0 \\
\hline Data analysis & 1666 & 48.1 & 1788 & 51.6 & 9 & .3 \\
\hline Findings & 498 & 14.4 & 2961 & 85.5 & 4 & .1 \\
\hline Suggestions & 2987 & 86.3 & 473 & 13.7 & 3 & .1 \\
\hline Abbreviation & 3011 & 86.9 & 452 & 13.1 & 0 & 0 \\
\hline Reference & 3169 & 91.5 & 294 & 8.5 & 0 & 0 \\
\hline
\end{tabular}

When Table 1 was analyzed, it was seen that the purpose is $90.5 \%$ in the abstract sections of the doctoral dissertations, approximately $9 \%$ of the abstracts did not include the purpose, and $0.4 \%$ the purpose is improper. The academic tone was used in the vast majority of abstracts (93.3\%). However, it can be stated that academic tone was not used leastwise $(6.7 \%)$. The research design was included in more than half $(56.1 \%)$ of the abstracts, and less than half of the abstracts did not mention the research design (43.9\%). It was seen that there was a quite amount of abstracts in which the research design was not stated. While the research sample was present in two-thirds $(76 \%)$ of dissertations, it did not exist in $23.9 \%$. It was stated incorrectly in the four of the abstracts. How the sample used in the dissertation was obtained (sampling method) was absent in most of the abstracts $(84.8 \%)$, while it was found in $15.1 \%$. How the data used in the dissertation had been collected was stated in $56.3 \%$ of the abstracts but not expressed in $43.6 \%$. Data collection tools used in the dissertation were included in $64.4 \%$ of the abstracts, while $35.6 \%$ was lack of it. Only in one dissertation was it stated incorrectly. While $51.6 \%$ of the abstracts included which statistical methods were used to analyze the data, $48.1 \%$ did not have it. In $0.3 \%$ of the abstracts, it was given incorrectly. The majority of the findings obtained in the dissertation were included (85.5\%), while $14.4 \%$ were not. In $0.1 \%$ of the abstracts, it was given incorrectly. While the suggestions were not included in most abstracts $(86.3 \%)$, it was included in $13.7 \%$ of them. In $0.1 \%$ of abstracts, it was stated incorrectly. While $86.9 \%$ of dissertation abstracts did not contain abbreviations, $13.1 \%$ had abbreviations. While $91.5 \%$ of abstracts did not include any reference, $8.5 \%$ of abstracts included them. The doctoral dissertation abstracts show a problem, especially in the sampling method, research design, data collection, data analysis, sampling, and findings.

In the dissertation review process, primarily "the purpose of the dissertation", which is one of the criteria determined in common in many dissertations writing guides and literature, was examined. Following the coding set out above, 314 dissertation abstracts did not have a purpose sentence. From these dissertations, in the abstract of the dissertation 20101013, 
"The variety in magazines, which are published at certain time intervals, where information and thoughts about specific subjects are conveyed, is increasing day by day. Children's magazines are printed communication tools that have functions such as improving the child's thinking, language and reading skills, making the time he spends outside the school of higher quality, educating, raising and entertaining the child."

After giving the quoted general information about the subject in the scope of the research, the research group was defined, and no information about the purpose of the research was given. It is regarded as an important problem, at the doctoral level, to come across dissertations where "purpose" is not stated. On the other hand, there are 3135 dissertations with purpose sentences. In the abstract part of the dissertation 20111304, which is one of these dissertations, the purpose of the study is stated clearly:

"In this research, the effect of the subjective well-being intervention program on the subjective well-being levels and the styles of coping with the stress of university students has been examined."

When the abstracts are analyzed in terms of academic tone, it is seen that in the abstracts of 233 dissertations, a language of expression far from an academic tone is used. As an example of these dissertations, when the language of the dissertation 20101005 is examined, "Translation education in universities today is directed towards specialization in different fields such as literary, oral or specialty translation. Our present aim in this study is to examine the specialization translation education starting from the historical stages, to give place to the theoretical and practical studies in this field in the world and in Turkey, and to provide insight into what the future in this area is." It is seen that the abstract is written in a language that is far from the academic tone, and the active voice is used. On the other hand, there are 3230 dissertation abstracts that properly used an academic tone. The dissertation 20161034 is an example:

"The main purpose of the research is to examine the historical development of the administrative structure and the executive training process of the education system in Turkey; for this purpose, related literature was reviewed, and the Republic of Turkey in the present regulatory organization, the National Education Council, in the Development Plan ..."

When the dissertation abstracts were examined in terms of the research design, it was seen that the research design was not given in 1520 abstracts (43.9\%). For example, in the abstract of the dissertation 20101045, it states:

"It was investigated whether the creation of teaching environments was effective in the elimination of students' misconceptions about social studies lesson learning levels and social studies concepts which are the building blocks of learning. As a result of the research; learning environments suitable for students' learning styles..."

As it is seen, after mentioning the purpose of the research, it was directly switched to the research results, and no information was given about the design of the research. The absence of research design in so many dissertations reveals a critical problem in this regard. The research design was stated in 1943 dissertations (56.1\%). As an example of these dissertations

"In the study, Nested Pattern, which is one of the mixed pattern types, where the quantitative approach is dominant, and the quantitative approach is supported with a qualitative approach is used."

In the dissertation 20171120, it was seen that the model of the research was clearly expressed.

When the dissertation abstracts were analyzed in terms of sample size, it was seen that while the sample size was correctly stated in 2631 dissertation abstracts, there 
was no information about the sample size in 828 dissertation abstracts. For example, in the dissertation 20161049 abstract it states,

"A survey was conducted, and activities were formed in order to reveal the difficulties that the students come from Afghanistan to Turkey have encountered in learning Turkish and to reveal their learning status".

As seen in the statement, no information was given about how many people the sample group consisted. The fact that the sample size was not given was seen as a significant deficiency. Regarding the number of samples, in the dissertation 20121419 abstract

“... the sample consists of a total of 20 students studying at 2, 3 and 4 grades at Afyon Kocatepe University studying bow instruments in Music in the 2010-2011 academic year, 14 of whom are violinists and 6 of them are violists."

It was seen that numerical information about the individuals included in the sample was given. In addition, in the dissertation 20121310 abstract, which states:

“... Selçuk University, which provides education and training in Konya in the 2010-2011 academic year, was determined as the universe. The sample of the research consists of Selçuk University Ahmet Keleşoğlu Faculty of Education, Department of Art Education, undergraduate students, and Selcuk University Faculty of Fine Arts undergraduate students."

It was seen that although there was a desire to provide information about the sample size, it could not be achieved as no numerical value was given. For this reason, it was evaluated as given incorrectly.

When the dissertation abstracts were examined in terms of the sampling method, it was observed that while the sampling method was given in 2938 (84.8\%) dissertation abstracts, $524(15.1 \%)$ dissertation abstracts did not include it. In the dissertation 20151003 abstract it states:

"For this purpose, the research was carried out with 980 students from 16 universities determined by stratified sampling method."

Also, in the dissertation 20151024, it states:

"The sample of the study, which was randomly selected, consists of 767 students from 4 Police Vocational High Schools from 4 geographical regions of Turkey and 28 instructors teaching Police Ethics courses".

It was clear that the sampling method was explained only in a statement. There were also abstracts in which the sampling method was not provided, such as in the dissertation 20101007 abstract:

"The sample of the study consisted of 586 kindergarten students and their teachers and mothers in Istanbul in the 2008-2009 academic year. The mothers constituting the sample group, the Parent Self-Efficacy Scale, which was adapted to Turkish by the researcher, was again selected by the researcher."

Although there was information about the number of samples, no information was given about the method by which the sample group was selected.

In the dissertation 20141073, information about how the data was collected is provided as

"...In the qualitative part of the research, the data were collected through semi-structured interviews with focus group students, focus group interviews and student science diaries during and after the experiment process...".

Similarly, in the 20141117 dissertation the information was given as 
“...the data were collected from international refereed journals and Turkish research articles from national refereed journals. The resumes of the American academic writers were examined on personal and corporate websites, and their education (Master's and Doctorate) was completed in the departments and academics working at a university were selected."

In the dissertation 20101004, it was also stated by the field experts that

"the quality of the techniques is more important than the quantity, and the use of the most useful method and technique for social studies falls greatly on field research. It has been investigated whether learning has an impact on overcoming the misconceptions of social science concepts that are building blocks.".

It is seen that there was no information about how the data was collected.

When the data collection tools were analyzed, information about the data collection tools was provided in 1233 (35.6\%) dissertation abstracts, while information about the data collection tools was not found in 2229 (64.4\%) dissertation abstracts. The information about the data collection tools was given in the dissertation 20151048 as,

"The data in the research were collected with the Adaptive Leadership Scale and the Motivational Language Scale for School Principals",

and again in the dissertation 20151059 as

"In order to collect data in the research, the Value Orientation Scale and the Motivational Action Conflicts Scale were applied three times at different time intervals (when the sessions started, completed and three months after they ended)".

There were abstracts that did not provide information on data collection tools. In the abstract section of the dissertation 20101015 which states:

"... how the developing literacy of the child directly affects the success in the school and how the mothers from different education and income levels guide their children aged 3 and 5 in the context of reading books together as a speech event; in other words, to what extent mothers' verbal interaction styles depend on education and income levels and the age of their children... ",

There was no information about which tool was used to collect the data from the mothers.

When the data analysis method was examined, there was information about the data analysis method in 1666 (48.1\%) dissertation abstracts. However, there were no data analysis information in $1788(51.6 \%)$ dissertation abstracts. Information on the analysis method was given in the dissertation 20151065 as

"Covariance Analysis (ANCOVA) was used in the pre-test-post-test comparisons, and the t-test was used for the related samples in the post-test-permanence test comparisons."

and in the dissertation 20151070 abstract it was stated as

"In the analysis of the research data, SPSS 13.00 and Lisrel 8.80 package programs were used. Path analysis technique was used to verify the structures of the scales. For non-parametric tests, Kruskal Wallis H-test, Mann Whitney U-test, and Wilcoxon Signed Ranks test were used for unrelated measurements. Also, Pearson Moments Product Correlation Coefficient, multiple linear and hierarchical regression analysis were applied."

There were abstracts without information about data analysis. The last paragraph of the dissertation 20111002 abstract states

“...111 Communication Course; basic concepts, verbal communication, non-verbal communication, written communication, and business life, and communication subjects were taught to the experimental group by web-based teaching method and to the control group by traditional method for eight weeks. On the other hand, opinion determination forms in the qualitative method were interpreted." 
And no analysis method was mentioned. There were also abstracts where the data analysis method was erroneous. For example, in the dissertation 20111036 abstract it was seen that the methods of analysis were incorrectly expressed as it states:

"... After the validity and reliability tests of the scales were applied, the sample was applied to the groups between 15 March and 30 June 2010. "Percentage", "Frequency", "Independent Sample One-Way Variance Analysis (ANOVA)", "Related Sample One-Way Variance Analysis (ANOVA)", "Bonferroni Test" and "Tukey Test" were used in the analysis of the data".

When the dissertation abstracts were examined about whether the findings were included, it was seen that the findings were included in the 2961 (14.4\%) dissertation abstracts and the information about the findings of the study was not included in 498 dissertation abstracts (85.5\%). In the dissertation 20121501 abstract, the findings of the research were given as

"As a result of the research, there was a significant difference in the hearing levels of the students depending on the criteria of deciphering solfeggio, weighing, dictation, and harmonic intervals, after the modal practices performed for 14 weeks."

However, in the dissertation 20101003 abstract, it was seen that the abstract of the dissertation was over, and there was no evidence for any findings:

"it was applied practically for 10 weeks. According to the pretest and posttest results, the performance differences of the experimental and control groups were compared. In addition, the opinions of the students in the experimental and control groups regarding the study were taken in writing. The data obtained were evaluated with the help of SPSS (V10.0) software, using "Paired T-Test" and "Mann Whitney -U Test".

In the examination of whether suggestions were included in the abstract content, it was found that no suggestions were included in the 2987 (86.3\%) dissertation abstracts. In the content of $473(13.7 \%)$ dissertation abstracts, suggestions regarding the study were presented. It was seen that the suggestions of the study were presented in the dissertation 20121467 abstract in the sentence,

"Accordingly, it can be suggested to apply the lesson model with small groups in teaching practice lessons and to focus on the applications that teacher candidates will carry out as a group in the planning, implementation and reflection cycle."

The dissertation 20131241 abstract was concluded without any suggestions:

“... Problem-solving activities with the group carried out in D1 were more effective in the problem-solving process by taking the problem-solving steps. Depending on the results at the end of the study, some suggestions have been made to the researchers and educators who will work in this field."

As a result of the "abbreviations" in the abstracts, it was found that no abbreviation was included in 3011 (86.9\%) dissertation abstracts, but it was seen that abbreviations were used in $452(13.1 \%)$ dissertation abstracts. It was expected that there was no abbreviation in the abstract (Aktaş \& Uzuner-Yurt, 2015). The dissertation 20121339 abstract can be an example of the abstracts with abbreviations:

"The aim of this study is to develop a reliable, valid, and useful performance test that will positively affect education-teaching in the musical reading (solfege) dimension of MIOY course in Music Education Departments of Education Faculties."

On the other hand, it was seen that there was no abbreviation sample in the dissertation 20101016 abstract.

When the "reference" in the abstracts was investigated, it was seen that there was no reference in the content of 3169 (91.5\%) dissertation abstracts, while there was a 
reference in $294(8.5 \%)$ dissertation abstracts. It was stated there should not be a reference in the abstract (KTU, 2004). For example, the dissertation 20121988 abstract can be shown as an example of the studies using reference:

"Although there is no common opinion about who is gifted, what are the gifted criteria, or how to determine gifted individuals, when the theoretical approaches to explain giftedness are examined, the common emphasis in these theories is that it is individuals that differ from normal individuals in terms of distribution, frequency, timing and composition of their physical, mental, social and personality traits (Akarsu, 2004)."

On the other hand, it was seen that there was no reference in the dissertation 20121342 abstract.

The second concern of the present study was to analyze whether there was a statistical difference between gender over the years. In line with this concern, the following findings were achieved.

The distribution of 3463 doctoral dissertations evaluated within the scope of the research by years and gender and chi-square tests are presented in Table 2.

Table 2

Distribution of Doctoral Dissertation by Gender over the Years and Chi-Square Test

\begin{tabular}{|c|c|c|c|c|}
\hline Year & & Female & Male & Total \\
\hline \multirow{3}{*}{2010} & $f$ & 202 & 263 & 465 \\
\hline & & & & \\
\hline & $\%$ & 43.4 & 56.6 & 100 \\
\hline \multirow{3}{*}{2011} & $f$ & 240 & 260 & 500 \\
\hline & & & & \\
\hline & $\%$ & 48 & 52 & 100 \\
\hline \multirow{3}{*}{2012} & $f$ & 266 & 259 & 525 \\
\hline & & & & \\
\hline & $\%$ & 50.7 & 49.3 & 100 \\
\hline \multirow{3}{*}{2013} & $f$ & 261 & 265 & 526 \\
\hline & & & & \\
\hline & $\%$ & 49.6 & 50.4 & 100 \\
\hline \multirow{3}{*}{2014} & $f$ & 273 & 289 & 562 \\
\hline & & & & \\
\hline & $\%$ & 48.6 & 51.4 & 100 \\
\hline \multirow{3}{*}{2015} & $f$ & 196 & 234 & 430 \\
\hline & & & & \\
\hline & $\%$ & 45.6 & 54.4 & 100 \\
\hline \multirow{3}{*}{2016} & $f$ & 160 & 146 & 306 \\
\hline & & & & \\
\hline & $\%$ & 52.3 & 47.7 & 100 \\
\hline
\end{tabular}




\begin{tabular}{lcccc}
\hline & $f$ & 73 & 76 & 149 \\
& $\%$ & 49 & 51 & 100 \\
Total & $f$ & 1671 & 1792 & 3463 \\
& $\%$ & 48.3 & 51.7 & 100 \\
\hline
\end{tabular}

$\chi^{2}=9.22, s d=7, p=.237$

When Table 2 was examined, it was seen that the most dissertations were written in 2014 ( $f=562,16.2 \%)$, and the least dissertations were written in 2017 ( $f=149,4.3 \%)$. Between 2010 and 2017, a total of 3463 theses on education were written, including $465,500,525,526,562,430,306$ and 149, respectively. The number of dissertations increased between 2010 and 2014 and then started to decrease.

When analyzed by gender, the ratio of theses written by women in doctoral dissertations on education between 2010 and 2017 is $43.4 \%, 48 \%, 50.7 \%, 49.6 \%$, $48.6 \%, 45.6 \%, 52.3 \%$ and $49 \%$, respectively. Although the number of theses written by women and men is close to each other, it can be stated that women wrote more dissertations than men in 2012 and 2016, while men wrote more dissertations than women in other years.

In order to examine whether these differences were significant, a chi-square analysis was performed. According to the results of the analysis, it was found that the number of doctoral dissertations did not differ significantly between genders $\left(\chi^{2}=9.22\right.$, $s d=7, p>.05)$. Accordingly, the numbers of male and female authors were similar in writing doctoral dissertations over the years. This shows the positive developments in terms of gender equality in Turkey.

\section{Discussion and Conclusion}

Within the extent of research, it is observed that the number of doctoral dissertations related to education does not differ significantly in the terms of gender and year. The fact that women do the same or a similar number of academic studies as men could be interpreted as an improvement. It can be stated that Turkey's education, in the sense of equal opportunity, is equal in terms of gender, even at the doctorate level. This finding is in line with the TSI's data on the enrollment rates of girls and boys in 2016 (TSI, 2017). This finding coincides with Özbilgin and Healy's (2004) findings that display that women are more involved in academic life. Furthermore, as CHE statistics indicate (Academic Staff Numbers Summary Chart; see also: https://istatistik.yok.gov.tr/), it coincides with the information of an equal number of male and female research assistants.

In the abstracts of the doctoral dissertations, it was observed that the sampling method was not included in $84.8 \%$, the data analysis was not included in $48.1 \%$, the research model was not included in $43.9 \%$, the data collection was not included in $43.6 \%$, sampling was not included in $29 \%$, and the findings were not included in $14.4 \%$ of the dissertation abstracts. It was concluded that there is a lack of methodology exclusively in these areas. Similarly, Tavşancil et al. (2010) also state in their study, 
examining postgraduate dissertations, that the expressions are used in a way that is unsuitable to the scientific research methods and techniques, and that the research is not conveyed well enough in the means of purpose, method, findings, and results that provide the research in a guiding structure to other researchers. As Berkenkotter and Huckin (1995) state, in the means of deciding whether to read the research, researchers initially look at the title and abstract of the research.

Although it is relatively less, it is seen that the purpose of the research is not stated in \% 9.1, and the language used is not included in \% 6.7. Like the present study, the study of Tavşancil et al. (2010) regarding the academic language used in the abstracts, which investigated the dissertation abstracts in terms of language under three subtitles such as "suitability for report language", "third-person use in narration" and "avoiding expressions without information" also produced the same results, indicating that in doctoral dissertations, the language use was not consistent with the academic criteria reflecting the lack of competence of the students in these areas. Considering the importance of the influence of dissertation writing guides in creating a standard structure, as stated by Ülker (2012), it is seen that the universities which obtain dissertation writing guide are superior in the ranking of textual components of the abstracts than the universities that do not have a writing guide.

In this research, abstracts of doctoral dissertations were examined, and some disadvantages were encountered. It is suggested that the postgraduate seminars/courses or Research Methods courses, which would help new researchers, postgraduate students to be more informed about the proper way of abstract writing, which is the general picture of any study (Berkenkotter \& Huckin, 1995; Salager-Meyer, 1990), to be carried out more efficiently at universities. In this research, dissertation abstracts in education were examined. Further studies focusing on dissertation abstracts written in different fields besides education and various parts of dissertations would provide better insight into the improvement of academic work and better dissertation work.

Considering these insufficiencies in the dissertation abstracts, it would be advisable to pay more attention to the current student advisory and dissertation supervision system. More student-supervisor meetings should be organized through regular intervals and more frequently to improve academic quality and academic writing skills to improve academic progress.

The doctoral dissertation abstract differences among universities or even among the programs of the same university in Turkey make it difficult to get an idea about the dissertations. It is recommended that in the institutes' dissertation writing guides, the dissertation abstract be expressed in a new national template considering the required qualifications.

\section{Statement of Responsibility}

Nuri Can Aksoy; conceptualization, document analysis, data analysis, investigation, resources, writing -original draft, writing -review \& editing. Ersoy Karabay; conceptualization, methodology, document analysis, data analysis, writing review \& editing. Esra Eker Durmuş; writing, document analysis, writing -review \& editing. Mehmet Göktaş; writing, document analysis, writing -review \& editing. Fatma Çiloğlan Konur; writing, document analysis, writing -review \& editing. 


\section{References}

Akarsu, F. (2004): Üstün Yetenekliler. Şirin, MR., Kulaksızoğlu A, \& Bilgili A., E. (Eds.), I.Türkiye Üstün Yetenekli Çocuklar Kongresi Makaleler Kitabı (pp. 127154). Çocuk Vakfı Yayınları, Yayın No:64, İstanbul.

Aktaş, E., \& Uzuner-Yurt, S. (2015). Türkçe eğitimi alanındaki makale özetlerine yönelik bir içerik analizi. Turkish Studies, 10(7), 73-96.

Berkenkotter, C., \& Huckin, T. N. (1995). News value in scientific journal articles. In Berkenkotter, C., \& Huckin, T. N. (Eds.) Genre knowledge in disciplinary communication. (pp. 27-44.). Routledge.

Bhatia, V. K., \& Genre, A. (1993). Language use in professional settings. Applied Linguistics and Language Study. Longman.

Bogdan, R. C., \& Biklen, S. K. (1998). Qualitative research for education: An introduction to theory and methods. Allyn and Bacon.

Brett, P. (1994). A genre analysis of the results section of sociology articles. English for Specific Purposes, 13(1), 47-59.

Büyüköztürk, Ş., Kılıç-Çakmak, E., Akgün, Ö. E., Karadeniz, Ş., \& Demirel, F. (2017). Bilimsel araştırma yöntemleri. Pegem Akademi.

Catalyst. (2019). Women in Academia: Quick Take - Catalyst. Retrieved from https://www.catalyst.org/research/women-in-academia/ on November 11, 2019

Chan, S. K., \& Foo, S. (2000). "Writing abstracts for scholarly communication by Asian ESL research scholars: Preliminary findings". Presented at Research and Practice in Professional Discourse Conference. City University. Hong Kong.

Chan, S. K., \& Foo, S. (2001). Bridging the interdisciplinary gap in abstract writing for scholarly communication. GENRE 2001 (Genres and Discourse in Education, Work and Cultural Life: Encounters of Academic Disciplines on Theories and Practices).

Councils of Higher Education [CHE]. (2016). Retrieved September 17, 2019, from http://www.yok.gov.tr/documents/10279/29921725/100_2000_YOK_Doktora_Bur slari_Kitapcigi.pdf/

Councils of Higher Education [CHE]. (2018). 100/200 YÖK doktora bursları. Retrieved September 17 , 2019 , from https://www.yok.gov.tr/Documents/Yayinlar/Yayinlarimiz/2019/100_2000_YOK_ Doktora_Burslari_Nisan_2018.pdf

Councils of Higher Education [CHE]. (2019). Retrieved from https://istatistik.yok.gov.tr/ on September 17, 2019

Day, R. A. (2000). Bir bilimsel makale nasıl yazılır ve yayımlanır? (Çev. Gülay, Aşkar Altay). TÜBİTAK Yayınları.

Dos Santos, M. B. (1996). The textual organization of research paper abstracts in applied linguistics. Text-Interdisciplinary Journal for the Study of Discourse, 16(4), 481-500.

Dronberger, G. B., \& Kowitz, G. T. (1975). Abstract readability as a factor in information systems. Journal of the American Society for Information Science, 26(2), 108-111. 
European Union. (2013). She Figures 2012 Gender in research and innovation-statistics and indicators. Luxembourg: Publications Office of the European Union.

Fidel, R. (1986). Writing abstracts for free-text searching. Journal of Documentation, 42(1), 11-21.

Hall, G. M. (2013). Structure of a scientific paper. How to write a paper, 3, 1-5.

Holmes, L. (1997). Post-communism: An introduction. Duke Univ Pr.

Hopkins, A., \& Dudley-Evans, T. (1988). A genre-based investigation of the discussion sections in articles and dissertations. English For Specific Purposes, 7(2), 113-121.

Hovy, E., \& Lin, C. Y. (1999). Automated text summarization in SUMMARIST. Advances in automatic text summarization, 14, 81-94.

Hyland, K. (2000). Praise and criticism: Interactions in book reviews. In K. Hyland (Ed.), Disciplinary discourses: Social interactions in academic writing (pp. 41-62). Longman.

Karadeniz Technical University [KTU]. (2004). Fen bilimleri enstitüsü tez yazım kilavuzu.

Karagöl, E. (2020). Akademik yazma açısından bildiri özetleri. Ana Dili Eğitimi Dergisi, 8(2), 410-426.

Keogh, T. J. (1994). The structure of abstracts: Stylistic and structural elements in 48 scientific and technical abstracts (Unpublished doctoral dissertation). Louisiana State University.

Özbilgin, M., \& Healy, G. (2004). The gendered nature of career development of university professors: The case of Turkey. Journal of Vocational Behavior, 64(2), 358-371.

Ph.D. Study in the USA - A guide for 2020. (n.d.). Retrieved from https://www.findaphd.com/study-abroad/america/phd-study-in-usa.aspx.

Pinto, M., \& Lancaster, F. W. (1999). Abstracts and abstracting in knowledge discovery. Library Trends, 48(1), 234-248.

Salager-Meyer, F. (1990). Discoursal flaws in medical English abstracts: A genre analysis per research-and text-type. Text-Interdisciplinary journal for the study of discourse, 10(4), 365-384.

Savaş, G. (2018). Türkiye'de yaşayan bireylerin toplumsal cinsiyet eşit(siz)liği algıs1Gender (In)equality perception of individuals living in Turkey. Akdeniz Kadın Çalışmaları ve Toplumsal Cinsiyet Dergisi, 1(2), 101-121.

Swales, J. (1981). Aspects of article introductions. The University of Aston, Language Studies Unit.

Swales, J. (1985). Episodes in ESP: A source and reference book on the development of English for science and technology (Vol. 1). Pergamon.

Swales, J. (1990). Genre analysis. Cambridge University Press.

Swales, J. (2004). Research genres. Cambridge University Press.

Şen, E. (2019). Bilimsel makale özetlerinde üstsöylem belirleyicilerinin incelenmesi (Unpublished doctoral dissertation). Dokuz Eylül University.

Tavşancıl, E., Çokluk, Ö., Çıtak, G. G., Kezer, F., Yıldırım, Ö. Y. \& Bilican, S. (2010). 
Ĕ̌itim bilimleri enstitülerinde tamamlanmış lisansüstü tezlerin incelenmesi (20002008). Ankara Üniversitesi Bilimsel Araştırma Projesi Kesin Raporu.

Tenopir, C. (1985). Full-text database retrieval performance. Online Review, 9(2), 149164.

Türkiye İstatistik Kurumu [TÜİK]. (2017). İstatistiklerle kadın.

Türkiye İstatistik Kurumu [TÜIKK]. (2016). Istatistiklerle kadın.

U.S. Census Bureau. (2019, May 23). Number of people with master's and doctoral degrees doubles since 2000. Retrieved November 15, 2020, from https://www.census.gov/library/stories/2019/02/number-of-people-with-mastersand-phd-degrees-double-since-2000.html

Ülker, M. E. (2012). A comparative analysis of thesis guidelines and master thesis abstracts written in English at universities in Turkey and in the USA (Master Thesis). Middle East Technical University.

Williams, I. A. (1999). Results section of medical research articles: analysis of rhetorical categories for pedagogical purposes. English for Specific Purposes, 18(4), 347-366.

Yıldırım, A., \& Şimşek, H. (2008). Sosyal bilimlerde nitel araştırma yöntemleri. Seçkin Yayıncilik.

Yin, R. K. (1994). Discovering the future of the case study. Method in evaluation research. Evaluation Practice, 15(3), 283-290. 